FedUni ResearchOnline

http://researchonline.federation.edu.au

This is a Submitted Manuscript of an article published by Taylor \& Francis in Journal of Vocational Education \& Training on 08/11/2012, available online:

http://doi.org/10.1080/13636820.2012.738428 


\section{Pre-apprenticeships in Australia: Differing orientations and their policy implications}

Little has been published in the Australian VET literature on the topic of preapprenticeships, which are a loose type of preparatory courses for apprenticeships available in some trades. Nevertheless, pre-apprenticeships have been in existence for several decades. With continuing concern over skill shortages in Australia, the research study on which this paper is based investigated the role of preapprenticeship courses in addressing skill shortages in the electrotechnology, automotive and engineering trades, some of the largest 'traditional trades' in Australia, and those with sizeable numbers in pre-apprenticeships. The principal objective of the overall study was to determine whether the use of preapprenticeships increased the size and suitability of the supply of entrants to the traditional apprenticeships and whether pre-apprenticeships do or might increase completion rates in apprenticeships. The paper uses findings from the study to develop a typology of pre-apprenticeship courses, proposing two fundamental orientations and discussing whether different orientations towards preapprenticeships are compatible with one another.

Keywords: pre-apprentices; training policy; apprentices

\section{Introduction}

Pre-apprenticeships represent one strategy that has been used in Australia and other countries for many years to augment the supply of potential tradespersons. The usual arguments in favour of this approach have been two-fold. One, a supply-side argument, is that pre-apprenticeships better prepare young people for specific industries by exposing them to the expectations of workplaces employing apprentices and, as well, can often provide additional educational preparation for apprenticeship study. This strategy therefore argues that pre-apprenticeships augment the total supply of applicants suitable for selection as apprentices. The other is a demand-side argument, that preapprenticeships can have an effect on the overall demand for apprentices, and thus eventually the number of tradespersons, by increasing employers’ confidence in employing apprentices. That is, they can reduce the risk of employing apprentices, which has been shown to be a factor affecting propensity to recruit (Smith and Bush 2011). 
Since the global financial crisis began to affect employment in 2008, there has been a new emphasis in many countries on strategies to assist people into employment. Apprenticeship, and hence pre-apprenticeship as a preparation for apprenticeship, already gathering momentum in international interest (Rauner and Smith 2010, Dolphin and Lanning 2011), became of increasing interest to governments. An example has been England, where numbers in apprenticeships have grown from 175,000 commencements in 2005 to an estimated 400,000 in 2010 to (Marsh 2011).

The paper uses data from a national research study ${ }^{1}$ (Dumbrell \& Smith, 2007) which was carried out in three occupational areas served by traditional trade apprenticeships: electrotechnology, automotive and engineering trades. These trades were selected because all are generally viewed as being important to the economy, but also because are not homogenous - for example, electrotechnology is generally viewed as attracting higher quality applicants. The larger study set out to examine the current level of preapprenticeship provision in Australia; the nature of pre-apprentices and their perceptions of their courses; the nature of pre-apprenticeship courses: their perceived purpose and their curriculum, including work experience provision; and the role of preapprenticeships in improving entry rates and completion rates in apprenticeships.

This paper reports on the main findings of the empirical fieldwork in companies and training providers. It then uses data that emerged from the research to develop a dual typology of pre-apprenticeship courses - an equity/social inclusion orientation and an industry/skill formation orientation - and to consider whether the two major orientations are compatible. This further analysis was undertaken because the research showed that

\footnotetext{
${ }^{1}$ The study was funded by the National Centre for Vocational Education Research
} 
there was a strong emphasis, in both of the case studies undertaken, on assisting disadvantaged young people.

\section{Background and literature review}

This section begins with a brief overview of apprenticeship, since pre-apprenticeships are designed as the precursor to apprenticeships. Australia is regarded as one of the world's leaders in apprenticeship. Apprenticeships in Australia were concentrated in the traditional trades until the 1980s, at which time there were around 150,000 apprentices. Apprenticeships were mainly undertaken by young males (Ray 2001); the only trade in which young women were heavily represented was hairdressing. Twenty-seven years ago the first of a series of major changes to Australia’s apprenticeship system, the introduction of the Australian Traineeship System, was initiated by the Kirby Inquiry (Kirby 1985). Traineeships are apprentice-like contracts of training, at a range of qualification levels, frequently in occupational areas outside the tradition trades such as business and retail, and lasting for one or sometimes two years rather than the three or four years of apprenticeships (Smith and Smith 2011) Most of the recent growth in the Australian apprenticeship system can be attributed to 'non-traditional' industry areas and occupations (i.e. traineeship areas) which have risen considerably so that now trainees account for around twice the number of trade apprentices. The number of traditional apprentices in training has, however, also been rising since the mid-1990s, with a slight dip during the Global Financial Crisis. By December 2011, the numbers of apprentices and trainees in training reached 440,700, 3.8\% of the working population (National Centre for Vocational Education Research 2011), with about twice as many in 
traineeships as in apprenticeships. As part of the 1990s training reforms in Australia, adults and part-time workers were allowed full access to apprenticeships and traineeships.

In Australia, an apprenticeship always involves a job (ie all apprentices are employed) and a training provider (ie all apprenticeships involve completion of a qualification, usually at Certificate III level). The training provider may be a TAFE (Technical and Further Education) Institute or a private Registered Training Organisation (RTO). TAFE is the publicly-funded provider of vocational education and training, and other RTOs are increasingly able to access government-funded places, including places for apprenticeships. The term Registered Training Organisation covers all training providers, approximately 4000 in all, accredited to deliver VET qualifications. For apprenticeships, Registered Training Organisations provide the formal qualifications-based training, whether the training is based on their premises or at the place of employment.

Other parties apart from employers and employees are involved. Commonwealth and State governments fund different aspects of apprenticeships and maintain a policy interest in the area; State governments maintain databases of apprentices and their employers, feeding into the national apprenticeship and traineeship collection maintained by the National Centre for Vocational Education Research. Group Training Organisations grew up to take the burden and risk of employment of apprentices from individual employers, particularly in volatile industries; they employ the apprentices and 'lease' them out to host employers. They employ around 13\% of trade apprentices in Australia (National Institute of Economic and Industry Research 2010) and have a strong pastoral care involvement (Hill and Dalley-Tim 2008). In addition, trade unions and employer 
associations maintain a 'watching brief' on apprenticeships in their industry areas, contributing vigorously to developments and policy debates.

While traditional apprenticeships are now a smaller proportion of the apprenticeship system than the newer traineeships, they remain important and have a major place in the Australian consciousness about work. They also have vital importance in the development of infrastructure for many industries and particularly in the current Australian resource-sector boom. Thus any programs which improve the quantity and quality of applications for, and completions of, traditional apprenticeships are important. Pre-apprenticeships form one such program.

Identifying the precise origins of pre-apprenticeships in Australia is difficult because there is no clear definition. Foley and Blomberg $(2011,19)$ for example state that 'the [Australian] national VET provider collection is not equipped to accurately identify national pre-apprentice activity', identifying great variations among the States and Territories in Australia in the length, structure and qualification level of preapprenticeships. There are some programs known as pre-vocational programs (Toner and Woolley 2007), which are sometimes are-considered to be the same as preapprenticeships, and are sometimes seen as quite different. Bearing all these definitional difficulties in mind, pre-apprenticeships seem to have begun in the early twentieth century; they were used, for example, in the 1930s in New South Wales as part of measures to combat unemployment, and were widely delivered during the 1950s and 1960s (Ray 2001). Their existence is well documented by the 1970s, and by the end of that decade measures had been taken to expand the number of pre-apprenticeship courses 
(Ray 2001). At one time it was thought that the introduction of traineeships may have diverted interest from pre-apprenticeships as a means of initial engagement of young people in apprenticed trades; however traineeships have not proved an easy route into apprenticeships, partly due to resistance from trade unions (Smith, Comyn, Brennan Kemmis and Smith 2009). Dumbrell (2003) found that, while it was not possible to identify precisely the number of pre-apprenticeships commenced in Australia, there seemed to have been a decline during the 1990s. Total pre-apprentice enrolments in Australia in 1999 seemed to be around 27,000 (Dumbrell, 2003: 18).

Programs called 'pre-apprenticeships' exist in a number of other countries; however generally they do not appear to be exactly equivalent to the Australian model. Unlike the term ‘apprenticeship’ which tends to have a clear meaning within countries (although such meaning can vary considerably among countries), there is no single definition of pre-apprenticeship either within Australia or within other countries. In Canada and the US, the nature of 'pre-apprenticeship courses' varies among provinces and States; and a wide range of models similar to pre-apprenticeship have been trialled in the UK. Generally, pre-apprentice programs world-wide do not include employment, although in the US, one program provides stipends to participants (Martin and Smith 2011); most programs, however, seem to include unpaid work experience. Usually in Australia, preapprenticeships are unconnected with secondary schooling, although in the State of Victoria, pre-apprenticeships can be undertaken at school (Brown 2008), but in the United States they are quite often offered in schools. In the United States there seems to be greater emphasis on equity concerns than in Australia; many American programs are 
targeted at minority groups, whether young people or adults; this seems to be connected with the comparative difficulty of gaining apprenticeship positions which in trades like construction are tightly controlled by the trade unions (Conway and Gerber 2009; Worthen and Haynes 2009).

Despite the range of definitional difficulties, there is no doubt that pre-apprenticeships are generally viewed as 'a good thing'. In the Australian 'Apprentice Kickstart Initiative’ which was introduced in response to the Global Financial Crisis (Youth Studies Australia 2009), for example, significant resources were invested in pre-apprenticeship courses. A recent Australian government inquiry into apprenticeships (Commonwealth of Australia 2011) reported approvingly on pre-apprenticeships, while arguing for more consistency among programs to provide an assurance of quality.

If one major purpose of pre-apprenticeships is to improve the chances of completing a subsequent apprenticeship, then it is of importance to examine the literature on attrition and retention in apprenticeships. Attrition has been identified as a major concern in apprenticeships. Completion rates in Australian apprenticeships are around 50\%; rates vary among industry areas with food trades, for example, showing low rates of completion (Stromback and Mahendran 2010). Also of interest is the retention of the apprentices and trainees at the end of their contract of training into permanent jobs with their employers. Some progress has been made in understanding the causes of attrition from apprenticeships. Studies in Australia by Karmel and Misko (2009), Cully and Curtain (2001), Callan (2000a) have found that apprentices leave their contracts of 
training more often for job-related than training-related reasons. This finding has been reiterated in the recent government inquiry (Commonwealth of Australia, 2011: 11). However, Smith, Walker and Brennan Kemmis (2011) suggest that a simple distinction between job-related and training-related issues might be misleading, finding that the provision of adequate training, as an important employment obligation for apprentices, could not be disentangled from other employment obligations.

It has been argued (College Curriculum Services Unit 1990) that the chances of completing an apprenticeship are related to the characteristics of the apprentice as well as to the apprentice’s satisfaction with his or her job and/or training. For example, Callan (2000b) found that females, indigenous apprentices and those with literacy or numeracy difficulties were less likely to complete apprenticeships than others. Ball and John (2005) found that younger apprentices were less likely to complete. The implication of this for the study reported in this paper is that pre-apprenticeship programs might particularly assist those with certain characteristics to prepare better for an apprenticeship.

Suggestions for improving completion rates, from the Australian literature, have included the following:

- Clearer communication of the demands and expectations of the job and training (Kilpatrick, Falk and Hamilton 2002);

- Better matching of apprentices to employees (Callan 2000b; Bardon 2010);

- Better selection processes (Simon, Harris, Symons and Clayton 2000); and

- Better curriculum link from preparatory programs to apprenticeship programs (Simons et al. 2000). 
- Access to a mentor and support for groups with specific disadvantage (Sadler and Smith 2004).

A pre-apprenticeship program might be expected to help address these point by increasing understanding of the job among potential applicants for apprenticeship, helping employers choose with more confidence, and providing accredited training that can articulate into an apprenticeship qualification.

However, previous studies have not found conclusive data on the effects of preapprenticeship in apprenticeship completion rates. Toner and Woolley (2007: 25) point out that data on the subsequent destinations and achievements of ex-pre-apprentices is very limited. Karmel and Oliver (2011) found some positive effect, but great variation among trades.

\section{Research method}

The research study consisted of a number of stages, of which three are discussed in this paper: a statistical overview and then research in companies and in training providers. University ethics committee approval was gained for the study.

The first stage included an initial analysis of statistical data on preapprenticeships, involving analysis of unpublished data held by the National Centre for Vocational Education Research for the years 2000-2004. These data related to courses that were either labelled as pre-apprenticeships or had names such as 'prevocational' and also related to traditional trades. When these were identified, data were obtained on the 
characteristics of students enrolled in these courses. Data from this stage is included to provide a general overview of pre-apprenticeships in Australia at this time.

The next stage reported in this paper involved questionnaire surveys of apprentices through their places of employment, and structured interviews with their employers. An initial list of 42 enterprises was compiled using a variety of sources including input from members of the Reference Group, published lists of members of industry bodies and other public sources. From this list, 23 agreed to participate in the study, and 14 eventually did. These enterprises, in four States, employed between them approximately 1600 apprentices across Australia. The major objective of this stage was to capture differences between apprentices who had and had not undertaken preapprenticeship courses. The questionnaire asked apprentices whether they had undertaken a pre-apprenticeship (using sufficient questions to be able to cross-check whether the course really was a pre-apprenticeship) and then for those who answered in the affirmative, a range of questions about their pre-apprenticeship and their views about it. All respondents were asked questions about their apprenticeship, so that responses from ex-pre-apprentices could be compared with responses from those who had not done a preapprenticeship.

The final stage reported in this paper was carried out through training providers, and consisted of surveys of students undertaking pre-apprenticeship courses and two case studies. The survey instruments focused on their pre-apprenticeship course, their prior and concurrent working activities, and their planned destination. The questionnaire survey included 106 students in nine pre-apprenticeship courses in two States, eight in 
TAFE (public) colleges and one in a private training organisation. The training providers were recommended by the project reference group and other personal contacts.

The case studies consisted of longitudinal, qualitative studies of students in two pre-apprenticeship courses, one in a TAFE college in rural New South Wales and one in a private provider in metropolitan Victoria, the courses being respectively in automotive and electrotechnology. The private provider was also a Group Training Organisation. The training providers were approached for permission following recommendations. In these case studies, three visits were undertaken to the colleges: near the beginning, middle, and end of the course. The three visits enabled the researcher to track changes over the life of the course and examine attrition from courses and final destinations. At each of the visits, students were interviewed in groups. The course coordinator and teachers were interviewed, and two employers were visited during each case study. Teacher and course co-ordinator issues focused on background about the course, student issues, industry currency and work placements. Employer interviews focused on their involvement with the course and the RTO, and their views about the course and the calibre of its graduates. All focus groups and interviews, which lasted between 30 minutes and an hour, were taped and transcribed, with permission.

The inclusion of a range of research methods (Johnson and Onwuegbuzie 2004) was designed to provide a range of perspectives on the issue and to triangulate findings. Pre-apprentice voices were captured in two types of location, and the case studies provided the important dimension of context (Yin 1994). Following the completion of the 
fieldwork, the qualitative and quantitative data were analysed to answer the project research questions, and, subsequently, to create a typology of orientations to preapprenticeship courses.

\section{Findings}

The statistical analysis showed that about three-quarters of pre-apprenticeship students were males aged under 25, that pre-apprentices were disproportionately (compared with the general population) from non-capital city areas, and that they were disproportionately Indigenous people. Most (95\%) were enrolled in courses that were longer than 400 hours; the length of courses increased during the period analysed so that by $200463 \%$ of courses were over 720 hours while in 2000 only $45 \%$ were over 720 hours. About $45 \%$ of the students had Year 10 or below education as their highest level, compared with about 55\% with higher levels. In Australia Year 10 (age 15-16) has traditionally been seen as the lowest school-leaving milestone consistent with reasonable achievement, as most States offer a Year 10 examination and/or grade. Year 12 represents full completion of secondary schooling and eligibility for university entrance. Over the 2000-04 period there was an increasing (but still low) proportion of students with Year 9 or lower school levels (from 10\% to 15\%); the main fall in this period was in Year 11 leavers. The picture gained from these data is that pre-apprentices are generally young, that they tend to be drawn from disadvantaged rather than advantaged backgrounds, and that a large proportion do not complete secondary school. 
The second phase reported in this paper showed that the employers were generally in favour of pre-apprenticeships, with four of the 12 interviewed regarding their use as essential in recruiting apprentices, two regarding them as important, and five as useful. Most saw the benefits of pre-apprenticeships as weeding out unsuitable candidates for apprenticeships, and three employers said that pre-apprenticeships improved retention and completion rates in apprenticeship. None saw any disadvantages in pre-apprenticeships. A total of 255 questionnaires were returned from apprentices employed by these employers, about $16 \%$ of their apprentices. $40 \%$ of the respondents had previously undertaken a pre-apprenticeship or similar course and 92\% had completed it. Electrical apprentices were more likely than those in automotive trades to have done a pre-apprenticeship course, hence the data from this phase may disproportionately reflect electrotechnology trades. In relation to questions about the content of, and satisfaction with, their pre-apprenticeship course, $57 \%$ strongly agreed and a further $41 \%$ agreed that they had learnt a lot in their pre-apprenticeship course; and 40\% strongly agreed and 53\% agreed that they had enjoyed their pre-apprenticeship course. When asked about work placements, only one-third said that their pre-apprenticeship course had included a placement.

The following are the main findings comparing those who had done a preapprenticeship and those who had not. With relation to potential outcomes, of the $85 \%$ of apprentices who said they intended to do further study related to their apprenticeship, those who had done a pre-apprenticeship were significantly more likely to be planning further study than those who had not, suggesting a stronger attachment to the occupation and greater prospects of retention. In relation to the cohort of pre-apprentices, matching 
the survey data with national records on contracts of training, which was done on an individual basis, showed that those apprentices who had done a pre-apprenticeship were younger than those who had not, but were more likely to have completed Year 12 .

The final phase reported in this paper was carried out through training providers. The survey responses of pre-apprentices in nine courses found high levels of support for their course, with over $90 \%$ agreeing or strongly agreeing that they were learning a lot in their course. The automotive pre-apprentices were concentrated in the youngest age group, but as they were all in one course, this may not necessarily be typical. Electrotechnology preapprentices were concentrated more than other industry areas in the slightly older (18 to 20) years age group. Analysis by highest completed year of schooling showed that $72.3 \%$ of the electrotechnology pre-apprentices had completed Year 12 or $13^{2}$, compared with only $25.8 \%$ of the engineering and none of the automotive pre-apprentices. In total, $22.1 \%$ of the respondents had only completed Year 9 or Year 10. This finding supports the finding from the previous phase that electrotechnology students were more likely than students in the other industry sectors to have completed Year 12.

An interesting finding is that almost two-thirds (62.7\%) of the Phase 5 survey respondents in this final phase were working part-time at the same time as undertaking their pre-apprenticeship course; engineering students were least likely to have a job. Only one respondent had never had a part-time job. Over a quarter (29\%) had worked in a fulltime job previously; although only two had worked in the same industry area as their pre-

\footnotetext{
${ }^{2}$ In South Australia students can study Year 12 part-time to allow for concurrent working, creating a 'Year 13 '.
} 
apprentice course. These high rates of previous employment suggest that preapprenticeships are not necessary to induct young people to the world of work.

Responses to a question on motivation for undertaking the pre-apprenticeship were quite consistent across the industry sectors. The responses given to a set of provided reasons (in descending order) were that $59 \%$ said it was 'a good way to get into an apprenticeship' with the next most popular options being equal percentages (7.6\%) attributed to ‘missed out on an apprenticeship' or 'not sure if I wanted to do an apprenticeship'. $11.4 \%$ opted for 'other'. Thus it was clear that in students' minds, preapprenticeships were very closely tied with moving into apprenticeships.

There was considerable variation among industry areas in pre-apprentices' responses to a question about work placements (which was defined as 'time spent in a real workplace as part of the course'). Nearly all of the automotive (87.5\%) and the engineering (90.0\%) pre-apprentices, but only $23.9 \%$ of the electrotechnology preapprentices said that their course involved a work placement. The length of the placements varied, mostly between one and four weeks. The students were asked who organised the work placements. One-quarter said their training provider organised the placement; nearly 60\% claimed that they organised it themselves or with the help of their parents. These data, together with the data from the previous phase, suggest that work placements, in the industry areas where they were common, were not strongly managed by the training provider, supporting a point made by Toner and Woolley (2007) that providers found it difficult and costly to organise placements. 
Responses were positive on questions relating to learning from the course, but electrotechnology students seemed to be less satisfied than others with both their learning and their enjoyment—although the majority were still enjoying their course. Their more critical approach to their courses may possibly be related to their higher education level. Nearly all pre-apprentices expected to finish their course, but there was, however, a rather muted response to a question asking the extent of respondents' agreement with the statement 'my pre-apprenticeship course is assisting me with achieving my career goals'. Although three-quarters agreed or strongly agreed, only just over a quarter (27.6\%) were in strong agreement; and just under a quarter (22.9\%) were not sure. Qualitative comments from electrotechnology students on this question were mainly negative, while engineering students were more positive. However, 83\% stated that they intended going into an apprenticeship of all pre-apprentices.

A request for final comments from students included some very positive remarks.

- The lecturers are fantastic, very helpful and make the course thoroughly enjoyable! (automotive).

- I thank all the teachers for teaching me and my mates, [I] really really enjoyed coming and haven't missed a day (electrotechnology).

- I consider myself fortunate to be able to participate in this course (engineering).

The two case studies were designed, primarily, to provide a more in-depth picture than the pre-apprentice student survey. They also introduced teacher and employer perspectives. To provide some breadth, although only two case studies were carried out, they involved two different states, TAFE and non-TAFE sites, and metropolitan and rural locations. Details are provided in Table 1. 
Table 1 Case study details

\begin{tabular}{|l|l|c|l|l|}
\hline Name & Course & State & $\begin{array}{l}\text { TAFE/Non- } \\
\text { TAFE }\end{array}$ & Location \\
\hline Cable Co & Electrotechnology & Vic. & Non-TAFE & Metropolitan \\
\hline $\begin{array}{l}\text { Country Town } \\
\text { TAFE }\end{array}$ & Automotive & NSW & TAFE & Rural \\
\hline
\end{tabular}

That one of the case studies was in the automotive area somewhat redressed the balance of the survey of pre-apprentices, which had accessed very few automotive preapprentices.

The case studies are discussed below using the study’s research areas as a frame. The nature of the two courses and providers. Cable Co was a private non-profit company established by the employer and employee associations in the State of Victoria. It had been offering pre-apprenticeships for eight years and took several intakes each year. The company also ran off-the-job training for apprentices and other electrotechnology courses, and had a group training organisation with around 250 electrotechnology apprentices. The pre-apprenticeship course lasted for 600 hours but provided only approximately 160 hours' credit (six months of the off-the-job component) credit into an apprenticeship. 'Country Town TAFE' was a small rural TAFE campus also offering apprenticeship courses in automotive (and a range of other courses) and usually had two pre-apprentice intakes each semester. At Country Town TAFE, the pre-apprentices took most of their classes with the apprentices; this was not the case at Cable Co.

What were the characteristics of the pre-apprentices? At Cable Co the preapprentices in the course studied were all males aged between 17 and 23. Most had 
completed Year 12 and two had turned down university places to undertake the course. Most had part-time jobs, although a few had given them up because the course hours were so long. At Country Town TAFE, the pre-apprentices who attended the focus groups were more varied. There were two women, both with children, and one male in his mid-twenties; the remainder were males aged under 20. The Country Town TAFE group was not as sure as the Cable Co group that they definitely wanted careers in the industry; some were taking the course because of an interest in cars but not necessarily in an automotive career.

What did the pre-apprentices think of their course? Because only a few teachers were involved, the pre-apprentices at Country Town TAFE enjoyed the close relationship they had with the teachers. They particularly liked the practical work and received extra help with learning problems. They enjoyed the opportunity to work on their own cars or their friends’ cars. At Cable Co the students were not quite so satisfied; they tended to expect higher standards and found the course a little disorganised, with some modules not very interesting, but overall they too were satisfied. Despite being better educated, the electrotechnology students found their course more difficult than did the automotive students. All students tended to enjoy the practical work more than the theory work.

What is the role of work placements? In the electrotechnology course there were no work placements and in the automotive course placements were only offered to the most able students. In the latter case the course co-coordinator would have liked to extend the practice, had more resources been made available. In the former, the course coordinator 
said he was wary about possible exploitation by employers and would have preferred to spend additional resources on a more realistic simulated work environment.

Does the completion of a pre-apprenticeship facilitate entry to apprenticeships? In the electrotechnology industry in Victoria a pre-apprenticeship seemed to be more or less a requirement for gaining entry to an apprenticeship in the larger companies. Companies liked the fact that ex-pre-apprentices had basic skills and knowledge of the industry and that they had received extra maths tuition. In the automotive industry in the rural area of the case study, employers were not so decisive about a preference for pre-apprentices. However one student had already gained a part-time job in an automotive spare parts dealership, a job that, according to the employer, might equally be gained by a fullyqualified automotive mechanic. The employer said:

Her knowledge of what she's picked up so far in the apprenticeship(sic) has definitely helped her in the spare parts, identifying different parts of a vehicle... knowing what a ball joint is or what basic oil fluid is, rather than coming to me knowing nothing... she can look up parts books, mark stock off knowing what the product is.

In the Country Town TAFE case study the teachers felt that the course had succeeded not only if a student had gained an apprenticeship, but also if he or she had been rehabilitated from drug or alcohol problems or if he or she enrolled in another course. A few of their students said they still did not feel ready for work even near the end of the course.

The case studies provided a useful insight into the lived experiences of teachers and students in pre-apprenticeships. They provided evidence of the varied and complex motives for participation, a nuanced view of the teaching and curriculum and of students' 
and employers' views of the quality of these, and an insight into the differing views of successful outcomes.

\section{Discussion}

The discussion briefly addresses some of the main issues that the project set out to address, and then presents a new typology of pre-apprentice orientations.

Does completion of a pre-apprenticeship facilitate entry to an apprenticeship? The data collected in the study suggests that this is the case, but it is difficult to prove a causal relationship as many other factors intervene in the ‘articulation'. Certainly preapprentices appeared to anticipate entry to an apprenticeship, and employers viewed them favourably as candidates.

Are pre-apprenticeships likely to increase completion of apprenticeships? There are no direct data from this study but there is indirect evidence. Table 2 summarises some ways in which the programs address factors said to increase completion of apprenticeships as discussed in the background section of this paper.

Table 2: How pre-apprenticeships address factors said to increase apprentice completions

\begin{tabular}{|l|l|}
\hline $\begin{array}{l}\text { Factors said to increase completion of } \\
\text { apprenticeships }\end{array}$ & $\begin{array}{l}\text { Evidence from the study about possible } \\
\text { role of pre-apprenticeships }\end{array}$ \\
\hline $\begin{array}{l}\text { Clearer communication of the demands and } \\
\text { expectations of the job and training }\end{array}$ & $\begin{array}{l}\text { Pre-apprenticeships provide information } \\
\text { and skills in this area, but do not always } \\
\text { provide experience in workplaces. }\end{array}$ \\
\hline $\begin{array}{l}\text { Better matching of apprentices to } \\
\text { employees }\end{array}$ & $\begin{array}{l}\text { Prior experience of training provider and/or } \\
\text { employer through the applicant's } \\
\text { participation in a pre-apprenticeship is } \\
\text { likely to lead to sounder decisions }\end{array}$ \\
\hline
\end{tabular}




\begin{tabular}{|l|l|}
\hline Better selection processes & $\begin{array}{l}\text { As above. Also pre-apprenticeship course } \\
\text { results provide more data for the employer. }\end{array}$ \\
\hline $\begin{array}{l}\text { Better curriculum link from preparatory } \\
\text { programs to apprenticeship programs }\end{array}$ & Such links appear to be weak. \\
\hline Access to a mentor & $\begin{array}{l}\text { Pre-apprentice teachers could serve as } \\
\text { subsequent mentors in apprenticeships (this } \\
\text { was not tested) }\end{array}$ \\
\hline $\begin{array}{l}\text { Support to address disadvantage of specific } \\
\text { groups }\end{array}$ & $\begin{array}{l}\text { Country Town TAFE staff provided a great } \\
\text { deal of pastoral support for students. }\end{array}$ \\
\hline
\end{tabular}

The data from the survey in Phase 4 administered to apprentices accessed through their employers (the second phase reported in this paper) about post-apprenticeship study intentions provides additional insights. These data also-suggest that pre-apprentices are likely to have a more serious commitment to the occupation and an intention to progress further, compared with those who had not completed a pre-apprenticeship.

It has been argued that completion rates of apprenticeship might be facilitated if the term (three to four years) were shortened. A pre-apprenticeship could shorten the term by providing credit into the off-the-job study associated with the apprenticeship and/or by reducing the term of the apprenticeship. While the latter is a regulatory matter, the former can be addressed through curriculum construction. This topic was not specifically addressed in the study although the electrotechnology case study showed that in that industry pre-apprenticeships, although comparatively long in duration, did not gain a great deal of credit into the apprenticeship curriculum. It was reported that this was because of industry-specific issues possibly associated with licensing.

The issue of work placements proved quite problematic, as has been noted by Toner and Woolley (2007). The inclusion of work placements in a pre-apprenticeship 
curriculum might seem to serve several purposes: acculturating pre-apprentices to the industry, allowing them to practise their skills in context, and providing them with the chance to impress a future employer; all of these, it might be expected, would facilitate entry into an apprenticeship and might increase the chances of completion of that apprenticeship. Yet the provision of work placements was quite uneven, and in the electro-technology industry, particularly low.

The insights gained during the case studies led to a conclusion that there may be two major orientations to pre-apprenticeships: an equity/social inclusion orientation and an industry/skill formation orientation (Table 3). As discussed earlier, in official documents in Australia, the focus is on the latter, compared with, for example, the United States.

Table 3: Two orientations to pre-apprenticeships

\begin{tabular}{|l|l|l|l|l|l|}
\hline Orientation & Aim & Selection & $\begin{array}{l}\text { Training } \\
\text { emphasis }\end{array}$ & $\begin{array}{l}\text { Desired } \\
\text { outcome }\end{array}$ & Focus \\
\hline $\begin{array}{l}\text { Equity/social } \\
\text { inclusion }\end{array}$ & $\begin{array}{l}\text { To get } \\
\text { disadvantag } \\
\text { ed people } \\
\text { jobs }\end{array}$ & $\begin{array}{l}\text { Non- } \\
\text { selective or } \\
\text { targeted to } \\
\text { equity group }\end{array}$ & $\begin{array}{l}\text { Employability } \\
\text { skills and } \\
\text { work habits }\end{array}$ & $\begin{array}{l}\text { Any job or } \\
\text { another } \\
\text { training } \\
\text { course }\end{array}$ & The student \\
\hline $\begin{array}{l}\text { Industry/skill } \\
\text { formation }\end{array}$ & $\begin{array}{l}\text { To get good } \\
\text { workers for } \\
\text { the } \\
\text { occupation }\end{array}$ & $\begin{array}{l}\text { Selective on } \\
\text { merit }\end{array}$ & $\begin{array}{l}\text { Technical } \\
\text { skills and } \\
\text { knowledge }\end{array}$ & $\begin{array}{l}\text { Apprentice- } \\
\text { ship in the } \\
\text { occupation }\end{array}$ & Employers \\
\hline
\end{tabular}

Quotations from the two case studies neatly illustrate these two orientations:

Equity orientation: Country Town TAFE teacher

The best part of this job is getting people jobs ... when you get a kid or a

(local) person a job; it makes you feel good. I've done it hundreds of times

and that's the best part. 
Industry/skill formation orientation: Cable Co course co-ordinator

It makes the first year apprentice useful from day one, whereas if they haven't done a pre-apprenticeship course... basically they're a lunch boy or lunch girl and that's all they're good for initially. If they've done a pre-apprenticeship course, they know what a pair of pliers is, they know what a hacksaw is, go to the van, get a drum of cable, they know what type of cable to get, they know the difference between a step-ladder and an extension ladder.

Toner and Woolley (2007) have also pointed out two potential objectives of prevocational programs (they see pre-apprenticeships as part of the latter), referring to 'labour market efficiency' objectives and 'skill shortage' objectives. Our typology is more developed than this. We view equity and social inclusion as more comprehensive aims than merely labour market participation; and we consider that skill shortages are not the only issue in which industry has an interest; quality as well as quantity of supply of apprentices is important.

In Table 3, aims, selection processes, training emphasis, desired outcome for students, and focus are attributed to each outcome. Consideration even of our own data shows that any pre-apprentice course may borrow elements from each orientation, yet we believe that the two orientations hold as 'types'; it would certainly be possible to find individual courses that adhere to what Flyvberg (2006) would describe as paradigmatic cases. 
Some interesting conundrums arise. For example if the quality/social inclusion orientation considers employability skills and success in the labour market as essential elements of a pre-apprenticeship, what are we to make of the findings, from our Phase 5 the final-phase survey, that almost all pre-apprentices have worked previously, and that many are working concurrently with their pre-apprenticeship. This strongly argues against one of the common beliefs about pre-apprenticeship courses expressed by some respondents in other stages of the study-that pre-apprenticeship courses were designed to increase the 'work-readiness' of students. Unless the employers' expectations of apprentices are substantially different from those of other employers, such a purpose for pre-apprenticeships cannot be sustained on our evidence. However a proposition that preapprenticeships could develop employability skills applicable to a particular industry might be sustainable.

It should not be assumed that the two orientations in Table 3 are diametrically opposed. A concern for skill development in an industry does not mean that a concern for social inclusion is absent. Smith and Smith (2011) have shown in relation to traineeships that employers, while they may be assumed to be interested only in good quality applicants, in fact frequently demonstrate a commitment to social inclusion in their recruitment and training practices.

\section{Conclusion}


Toner and Woolley's twin typology of 'objectives' of pre-vocational programs leads to a suggestion on their part that pre-apprenticeships should be split into two 'streams'. Thus they advocate for the 'skill shortage’ stream to have rigorous selection procedures. But because individual programs (not to speak of teacher and student bodies) may include elements of each orientation, this seems difficult to achieve in practice. It would also be at odds with most other education programs in Australia, which are not labelled as being intended for either 'achievers' or 'the disadvantaged'.

It might be instructive to consider whether the differing orientations are necessarily a problem. Apprenticeship itself has been shown to have multiple objectives. Smith (2010) has identified four major viewpoints on apprenticeship: a passage to adulthood, a means of industry and national skill formation, a way of developing occupational identity and as a device for occupational restriction. Each of these four 'lenses' are variously claimed by different interest groups, for different purposes, to be the 'real' purpose of apprenticeship, but in the end all four can be seen in any apprenticeship. Thus there is no inherent difficulty with having two major orientations for pre-apprenticeship.

If we take this line, then the problem becomes not so much the purpose but the nature of pre-apprenticeship. The diversity among pre-apprenticeships has perhaps meant that as courses they have not been rigorously examined for quality. Our study showed some dissatisfaction among pre-apprentices with the curriculum and pedagogy in their courses. For example, the electrotechnology pre-apprentices noticed if the material was not up to date or if a particular teacher was not very effective. They attended for long hours and 
expected the time to be used well. Other indicators such as the low amount of credit into apprenticeships (and hence the implication that much of the pre-apprenticeship may just be 'padding' and not necessary to work in the industry) indicate, likewise, some quality issues. Were there to be more agreement on what should be involved in a preapprenticeship, irrespective of orientation, the courses might improve in quality and would certainly be easier to market to employers and students alike. It would also make it easier for other industries, that do not currently utilise pre-apprenticeships, to make an informed choice about whether to venture down this path. At the moment, for example, pre-apprenticeships might be seen either as prestigious or as low-level. This could be quite confusing for many stakeholders. As with apprenticeships (Smith, 2010: 314), literature on pre-apprenticeships rarely considers curriculum and pedagogy and there is a need for further research in this area.

In considering the study's implications for policy and practice, it is important to remember that the study looked at three trades only and the findings do not necessarily apply to other occupational areas. There were clear differences between some of the industry sectors examined. It follows that there might well be good policy reasons to encourage such diverse approaches on an industry basis, rather than to impose a 'one size fits all' model onto pre-apprenticeships. The Australian government's response to the recent Expert panel report's (Commonwealth of Australia, 2011: 15) request for a national definition for pre-apprentices was not taken up. The government response was rather that 'The Government will work with Industry Skills Councils to improve national consistency in preparatory training and requirements for qualifications, which may be 
used in preparatory training programs.' (Department of Employment, Education and Workplace Relations, 2011: 6). This implies a response focused on better curriculum and better recognition among stakeholders, as we have argued above.

We argue that it in any policy consideration of pre-apprenticeships, that the curriculum should be sufficiently flexible to enable a balance between industry-specific skills and more general work-readiness skills, depending upon individual students' needs. It also seems self-evident that as far as is reasonably consistent with the particular focus of a course, courses should incorporate appropriate and substantial units of competency which count towards units required to complete an apprenticeship, and a formal period of work placement.

It is clear that a great deal more research is needed into the nature and efficacy of preapprenticeships. There is a limit to both the quality and the utility of such research unless pre-apprenticeships are more clearly delineated in the national VET statistical collection. This of course would require national agreement on what pre-apprenticeships are and how they would be identified in the national data collection. It would also involve considerable attention being paid to the development of underpinning principles which could sufficiently incorporate both major orientations to pre-apprenticeships while allowing for comparability.

\section{References}


Ball, K. \& John, D. 2005. Apprentice \& trainee completion rates. Adelaide: NCVER.

Bardon, B. 2010. Trade apprenticeships completion analysis, unpublished paper for NSW Board of Vocational Education \& Training.

Brown, M. 2008. VETiS: How it works in Victoria. VOCAL 7: 19-31.

Callan, V. 2000a. Accelerated apprenticeships: Apprentice, employer and teaching staff perceptions, Adelaide: NCVER.

Callan, V (2000b). Report on apprenticeship and traineeship non-completions. Brisbane: Queensland Department of Education \& Training.

College Curriculum Services Unit (NSW TAFE) 1990. Apprenticeship separation analysis: Report of an investigation into the reasons for NSW apprentices separating from their trade. Sydney: NSW Department of Further Education, Training \& Employment.

Commonwealth of Australia 2011, A shared responsibility: Apprenticeships for the $21^{\text {st }}$ century, final report of the Expert Panel, Canberra: Commonwealth of Australia.

Conway, M., and A. Gerber. 2009. Construction pre-apprenticeship programs: Results from a national survey. Washington, DC: Aspen Institute.

Cully, M. and R Curtain. 2001. Reasons for new apprentices’ non-completions. Adelaide: NCVER.

http://www.australianapprenticeships.gov.au/ExpertPanel.asp

Department of Employment, Education \& Workplace Relations. 2011. Australian government response to 'Apprenticeships for the $21^{\text {st }}$ century' Expert Panel recommendations. Canberra: DEEWR. 
Dolphin, A. and T. Lanning. 2011. Rethinking apprenticeships. London: Institute for Public Policy Research. http://www.ippr.org/publications/55/8028/rethinkingapprenticeships

Dumbrell, T. 2003. Pathways to Apprenticeship, Adelaide: NCVER.

Flyvberg, B. 2006. Five misunderstandings about case-study research. Qualitative Inquiry 12, no 2: 219-245.

Foley, P and D. Blomberg. 2011. Pre-apprenticeship training activity, Adelaide: NCVER.

Hill, A. and L, Dalley-Tim. 2008. Hanging in there: What makes a difference in the first year of an apprenticeship. Youth Studies Australia 27, no.1: 36-42.

Johnson, R.B. and A. J, Onwuegbuzie. 2004. Mixed method research: a research paradigm whose time has come. Educational Researcher 33 no 7: 14-26.

Karmel, T. and J, Misko.2009. Apprenticeships and traineeships in the downturn, NCVER, Adelaide.

Karmel, T. and D, Oliver. 2011. Pre-apprenticeships and their impact on apprenticeship completion and satisfaction. Adelaide: NCVER.

Kilpatrick, S., I, Falk. and V, Hamilton. 2002. Issues of quality learning: Apprenticeships and traineeships in rural and remote Australia. Australian and New Zealand Journal of Vocational Education Research.10, no2: 1-26.

Kirby, P. 1985. Report of the Committee of Inquiry into Labour Market Programs, Committee of Inquiry into Labour Market Programs, Canberra: AGPS. 
Marsh, R. 2011. Apprenticeship quality and growth in England: An international perspective. ESRC Festival of Social Science: SKOPE Conference The Future of Apprenticeship? Westminster, London: Church House conference centre.

Martin, L. and R, Smith. 2011. Pre-apprenticeship urban workforce training programs. Adult Learning, 22 no 1: 23-27.

National Centre for Vocational Education Research (NCVER). 2011. Apprentices and trainees: 2010 annual statistics. Adelaide: NCVER

National Institute of Economic and Industry Research. 2010. Looking ahead. The future for group training: An industry and economic analysis, Sydney: Group Training Australia.

Rauner, F. and E, Smith. (Eds.) 2010. Rediscovering apprenticeship. Netherlands: Dordrecht.

Ray, J. 2001. Apprenticeship in Australia: A concise history. In Smart, N (Eds). Australian apprenticeships: research Readings, Leabrook: NCVER, 15-42.

Sadler, J. and V, Smith. 2004. Boosting your retention rates: Lessons for preventing early drop-out. London: Learning \& Skills Development Agency.

Simons, M., R, Harris., H, Symons., and B, Clayton. 2000. A national study of factors contributing to retention and completion rates of apprentices and trainees, Learning together, working together: building communities in the 21st century: proceedings of the 8th Annual International Conference on Post-Compulsory Education and Training, Gold Coast, 4-6 December.

Smith, E. 2010. Apprenticeships. In International Encyclopedia of Education, ed. P. Peterson., B. McGaw., and E. Baker, vol 8: 312-319. Oxford: Elsevier. 
Smith, E. and A., Bush. 2011. Apprenticeship and traineeship demand and supply: Employers’ views. Occasional Paper, Adelaide: NCVER

Smith, E., P, Comyn., R, Brennan Kemmis., and A, Smith. 2009. High quality traineeships: identifying what works. Adelaide: NCVER.

Smith, E. and A, Smith. 2011 Does the availability of vocational qualifications through work assist social inclusion? Education + Training, 53 no 7: 587-602.

Smith, E., A,Walker., and R, Brennan Kemmis. 2011. Understanding the psychological contract in apprenticeships and traineeships to improve retention. Adelaide: NCVER.

Stromback, T., and A, Mahendran. 2010. An Analysis of factors contributing to apprenticeship and traineeship completion. International Journal of Training Research. 8, no.1: 63-79.

Toner, P., and R, Woolley. 2007. Evaluation of pre-vocational training for the NSW Board of Vocational Education and Training. Sydney: Board of Vocational Education and Training.

Worthen, H., and A, Haynes. 2009. Outcomes of two construction trades preapprenticeship programs: A comparison. Journal of Community Practice 17, no. 1-2: 207-222.

Yin, R.K. (1994). Case study research: Design and methods, 2nd edn. Thousand Oaks, CA: Sage.

Youth Studies Australia. 2009. Youth initiatives: Apprentice kickstart package. Youth Studies Australia 28, no. 4: 64. 